\title{
PENGARUH KEBIJAKAN TARIFF IMPOR GULA TERHADAP PERMINTAAN GULA INDONESIA
}

\author{
Oleh \\ DR. Muhammad Emil Rahman, S.E., M.M. \\ Fajar Mutia Suri, S.E., M.M. \\ Jurusan Administrasi Niaga, Universitas Tulang Bawang Lampung \\ e-Mail : muhammad.emil.rahman@gmail.com
}

\begin{abstract}
ABSTRAK
Industri gula Indonesia masih tetap dihadapi dengan permasalahan dalam mencapai kemandirian pangan dimana untuk memenuhi pasokan konsumsi baik untuk rumah tangga dan industri selalu berbanding terbalik dengan produksinya. Keiikutsertaan Indonesia dalam berbagai perjanjian dan kesepakatan perdagangan seharusnya menjadikan peluang yang dimulai dari komitmen pada GATT dalam kesepakatan WTO dan CEPT pada kesepakatan AFTA dimana pada kesepakatan tersebut bertujuan untuk menciptakan pasar yang adil dan transparan khususnya untuk usaha pertanian sehingga menciptakan industri pertanian yang mandiri tanpa bantuan atau intervensi didalammnya. Pada tahun 2004 berbagai negara berkembang termasuk Indonesia memulai pelaksanaan konteks dalam perjanjian tersebut, pada kenyataannya muncul berbagai intervensi yang lebih mementingkan kepentingan domestik. Komoditas gula yang memiliki karakteristik tersendiri dibandingkan dengan komoditas lainnya, intervensi yang semakin ketat, perubahan harga yang berfluktuasi, dan kondisi produksi yang semakin bersaing dengan komoditas substitusinya menjadikan pasar gula Indonesia semakin sulit untuk mengembangkan dan mempertahankan stabilitas perekonomiannya
\end{abstract}

Kata Kunci: Kebijakan Tariff, Impor, Gula, Permintaan. 


\section{PENDAHULUAN}

\section{Latar Belakang}

Perdagangan gula dunia pada tahun 2015 berada pada angka 54.8 juta ton yang mencukupi permintaan gula dunia sebesar 54.4 juta ton. Gula sebagian besar diproduksi oleh 130 negara diseluruh dunia dengan total produksi sebesar 177.3 juta ton, diikuti total konsumsi sebesar 170.5 juta ton pada tahun 2014. Pada tahun 2015 produksi gula dunia menurun sebesar 164.9 juta ton dengan peningkatan total konsumsi sebesar 171.8 juta ton. Pada Mei 2016 total produksi gula dunia mencapai 164.9 juta ton dari total produksi tersebut sebesar 70 persen gula dunia dikonsumsi pada tingkat domestik negara-negara di dunia dan selebihnya diperdagangkan. Konsumsi gula dunia untuk periode tahun 2016 sampai 2017 diperkirakan akan mencapai angka 174 juta ton melebihi produksi dan stok yang terus berada di level terendah semenjak periode tahun 2010 sampai 2011. Rata-rata stok gula dunia pada periode tahun 2000 sampai 2007 adalah 55.9 juta ton dengan tingkat pertumbuhan sebesar 2.98 persen per tahun. Hanya sebagian kecil dari produksi gula dunia yang diperdagangkan secara bebas, namun perubahan kecil dalam produksi dan kebijakan pemerintah masing-masing negara cendrung memiliki dampak yang besar terhadap pasar gula dunia dimana harga gula menjadi tidak stabil (USDA 2016).

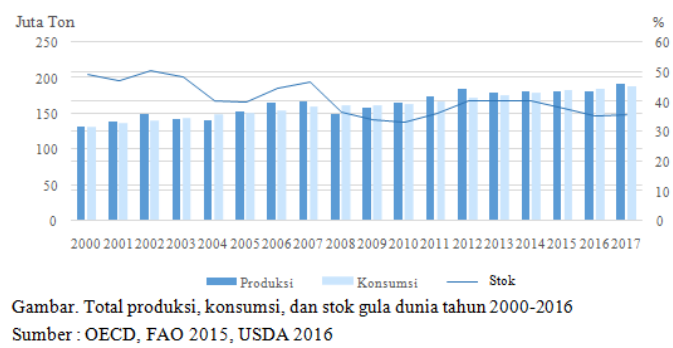

Ekspor dan impor gula dunia sebagian besar ditentukan oleh perjanjian preferensial dimana negaranegara pengekspor besar menikmati akses pada pasar domestik EU dan Amerika Serikat melalui jalur khusus. Perdagangan dibawah naungan perjanjian preferensial sangat penting untuk sektor gula negara-negara berkembang. Brazil, Thailand, Australia dan Guatemala merupakan negara pengekspor gula terbesar dengan jumlah total ekspor sebesar 68 persen dari seluruh ekspor gula dunia atau sebesar 32 persen dari total produksi gula dunia pada tahun 2015. India mencapai puncak tertinggi dalam mengekspor gula pada tahun 2011 namun periode seterusnya hingga tahun 2015 tercatat India mengalami penurunan ekspor dan produksi gulanya, hal tersebut disebabkan oleh buruknya hasil rendemen dan pengolahan tebu pada pabrik penggilingan.

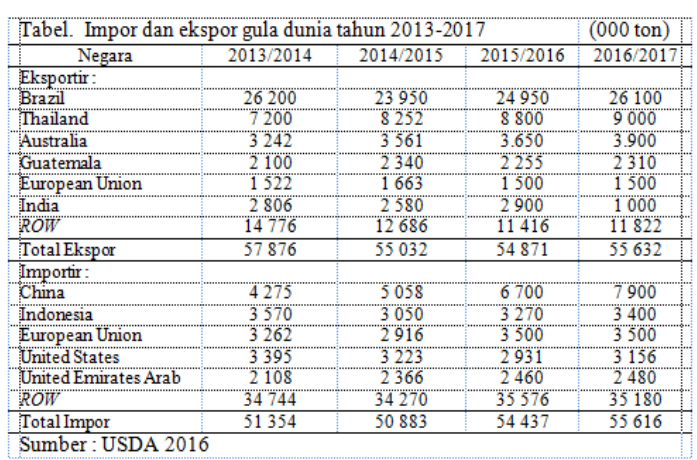


Industri gula Indonesia merupakan salah satu sektor strategis untuk menghadapi tantangan pada lingkup perdagangan di pasar gula dunia, hal tersebut dikarenakan terdapat faktor kapasitas sumberdaya pertanian khususnya perkebunan yang sangat melimpah seperti; iklim tropis yang memungkinkan sebagian tanaman berproduksi sepanjang waktu, areal pertanian yang luas, serta jumlah tenaga kerja pada sektor pertanian yang cukup banyak. Luas areal perkebunan tebu dibagi menjadi tiga menurut status pengusahaannya yaitu; Perkebunan Rakyat (PR), Perkebunan Besar Negara (PBN) dan Perkebunan Besar Swasta (PBS). Pada tahun 2013 luas areal perkebunan tebu Indonesia tercatat seluas 470.94 ribu hektar, kemudian meningkatan sebesar 0.37 persen menjadi seluas 472.67 ribu hektar pada tahun 2014. Pada tahun 2015 luas areal tanam tebu sedikit mengalami peningkatan seluas 474 ribu hektar (BPS 2015). Secara keseluruhan trend perkembangan luas areal tanam tebu di Indonesia periode sepuluh tahun terkahir mengalami penurunan dengan rata-rata luas areal sebesar 481 ribu hektar pertahunnya atau 0.06 persen pertahunnya. Penurunan luas areal tanam tersebut dikarenakan tidak adanya kepastian untuk memperbaiki atau menambah kapasitas pada pabrik penggilingan tebu sehingga petani lebih memilih untuk menanam tanaman padi atau jagung (Meylinah 2016). Tingkat produksi, impor dan konsumsi gula Indonesia periode 2013 sampai 2016 dapat dilihat pada gambar 1.5.

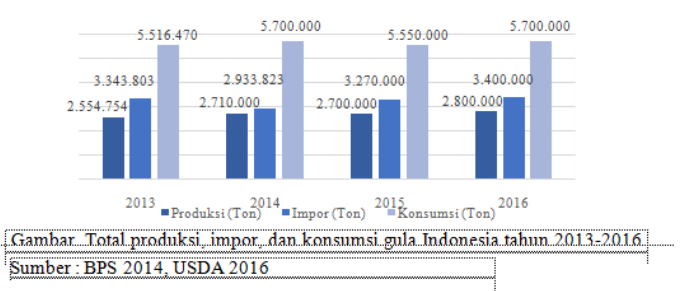

Pada tahun 2014 impor gula Indonesia mencapai 2.93 juta ton dengan nilai impor sebesar US\$ 1.31 juta. Volume impor gula Indonesia pada tahun 2015 mengalami peningkatan sebesar 14.87 persen dengan nilai impor mencapai US\$ 1.25 juta. Pasokan impor gula Indonesia terbesar selama 5 tahun berasal dari negara Thailand, Brazil, Australia, Afrika Selatan, Korea, dan Guatemala. Kontribusi negara terbesar pengimpor dalam sepuluh tahun terakhir adalah Thailand dengan jumlah ekspor gula ke Indonesia sebesar 1.79 juta ton dan besar nilai impor mencapai US\$ 649 juta atau 53.19 persen dari total impor gula Indonesia pada tahun 2015. Impor gula Indonesia dari Australia pada tahun 2015 mencapai 1.02 juta ton dengan nilai impor US\$ 374.38 juta, dan impor gula Indonesia dari Brazil sebesar 458.17 ribu ton atau 13.60 persen dari total impor gula Indonesia dengan nilai impor US\$ 189.95.

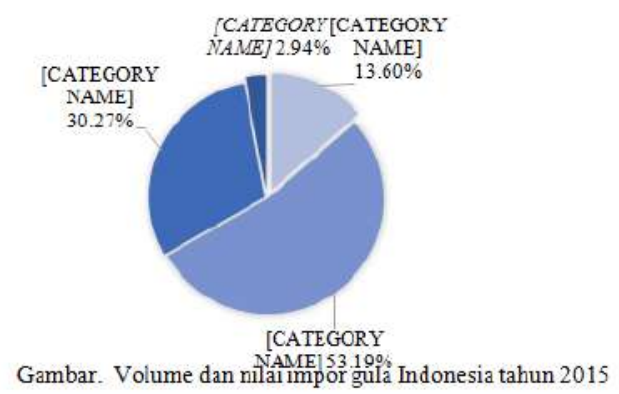




\section{Perumusan Masalah}

Industri gula Indonesia masih tetap dihadapi dengan permasalahan dalam mencapai kemandirian pangan dimana untuk memenuhi pasokan konsumsi baik untuk rumah tangga dan industri selalu berbanding terbalik dengan produksinya. Keiikutsertaan Indonesia dalam berbagai perjanjian dan kesepakatan perdagangan seharusnya menjadikan peluang yang dimulai dari komitmen pada GATT dalam kesepakatan WTO dan CEPT pada kesepakatan AFTA dimana pada kesepakatan tersebut bertujuan untuk menciptakan pasar yang adil dan transparan khususnya untuk usaha pertanian sehingga menciptakan industri pertanian yang mandiri tanpa bantuan atau intervensi didalammnya. Pada tahun 2004 berbagai negara berkembang termasuk Indonesia memulai pelaksanaan konteks dalam perjanjian tersebut, pada kenyataannya muncul berbagai intervensi yang lebih mementingkan kepentingan domestik. Komoditas gula yang memiliki karakteristik tersendiri dibandingkan dengan komoditas lainnya, intervensi yang semakin ketat, perubahan harga yang berfluktuasi, dan kondisi produksi yang semakin bersaing dengan komoditas substitusinya menjadikan pasar gula Indonesia semakin sulit untuk mengembangkan dan mempertahankan stabilitas perekonomiannya. Berdasarkan uraian pada latar belakang maka permasalahan dalam penelitian ini dirumuskan sebagai berikut :
1. Tingkat distorsi perdagangan gula dunia sangat tinggi dikarenakan negara-negara maju dan pengekspor gula terbesar melakukan intervensi yang kuat, mencakup kebijakan tarif, subsidi, dan jaminan harga untuk melindungi aspek perdagangan dan produksinya. Hal tersebut bertentangan dengan Agreement on Agriculture (AoA)dalam forum WTO yang menyepakati untuk mengurangi dukungan subsidi domestik (domestic support), subsidi ekspor (export competition) dan mengkonversikan hambatan impor kepada penurunan tarif (WTO 1999). Rata-rata harga gula dunia pada satu dekade terakhir sebesar US\$ 0.21 per pound atau dibawah rata-rata biaya produksi yang mencapai US\$ 0.49 per pound (Taylor 2016). Indonesia memberlakukan kebijakan tarif impor sebesar 10 sampai 25 persen, tarif tersebut tergolong sangat rendah jika dibandingkan negaranegara maju yang memberlakukan tarif impornya sebesar 25 sampai 50 persen.Distorsi pada industri gula dunia tersebut menimbulkan efek persaingan yang tidak adil pada aspek perdagangan dan produksi industri gula Indonesia.

2. Turunnya referensi pemerintah mengenai harga pokok tebu tingkat petani (HPP) pada kurun waktu terakhir menimbulkan isu-isu yang memperburuk keadaan industri gula di Indonesia. Pada tahun 2015, pemerintah menetapkan HPP sebesar Rp. 8900 per kg. Angka tersebut jauh dibawah HPP pada tahun 2012 dan 2013 yang mencapai Rp. 11800 dan Rp. 10250 per kg. 
Pemerintah Indonesia kemudian menetapkan HPP diatas Rp. 10000 per $\mathrm{kg}$, hal ini memberikan dampak terhadap penurunan luas lahan tanam tebu sebesar 469.000 hektar. Penurunan luas lahan tersebut akan menyebabkan penurunan jumlah produksi dan peningkatan jumlah impor gula Indonesia. Impor terbesar gula Indonesia berasal dari negara satu regional yang terus mengalami peningkatan produksi dan jumlah ekspor dengan luas lahan tanam tebu yang dimiliki Thailand mencapai 1.5 juta hektar di tahun 2015.

3. Kementerian perindustrian memperkirakan konsumsi gula nasional Indonesia pada tahun 2016 mencapai 5.8 juta ton yang terdiri dari 2.9 juta ton gula putih untuk konsumsi langsung pada pasar domestik dan 2.9 juta ton gula mentah untuk segmen industri berbahan baku gula. Pemerintah menetapkan pembatasan impor gula mentah sebesar 2.8 juta ton yang diperkirakan akan meningkat ditahun 2017 sebesar 3.2 juta ton.

4. Faktor yang menghambat perkembangan industri gula Indonesia salah satunya adalah terus menurunnya lahan tanam tebu. Mayoritas lahan tanam tebu di Indonesia dimiliki oleh individu hampir 95 persen dari bidang lahan tanam tebu di pulau Jawa. Sifat kepemilikan lahan yang dimiliki oleh individu tersebut rentan terhadap konversi, petani lebih memilih tanaman produktif selain tebu dan tinggi nya nilai bidang tanah seiring dengan kepentingan pembangunan perumahan dan bangunan komersial.
5. Indonesia saat ini memiliki 48 pabrik gula di Jawa dan 15 pabrik gula di luar Jawa yang dimiliki oleh 18 perusahaan. Mayoritas pabrikpabrik tersebut sudah beroperasiantara 40 sampai 100 tahun, hanya 6 pabrik yang beroperasi kurang dari 25 tahunsehingga produktivitasnya sangat rendah. Keseluruhan pabrik gula di Indonesia memiliki kapasitas total sebesar 245900 ton tebu per hari atau rata-rata untuk sebuah pabrik sebesar 3.900 ton tebu per hari dengan tingkat rendemen sebesar 7.1 persen. Angka ini rendah jika dibandingkan dengan negara satu regional ASEAN yaitu Thailand yang memiliki 50 pabrik gula dengan kapasitas yang lebih besar yaitu 94000 ton tebu per hari dengan tingkat rendemen sebesar 11.82 persen. Hasil yang didapat oleh Indonesia adalah seperempat dari hasil yang diperoleh oleh Thailand dengan kapasitas sebesar 10.6 juta ton tebu pertahun dan sebesar 8 juta ton untuk diperdagangkan (Wright dan Meylinah 2016).

Berdasarkan uraian permasalahan diatas industri gula Indonesia masih dihadapkan pada permasalahan yang kompleks, untuk menyederhanakan permasalahan dalam penelitian ini maka diperlukan penyusunan serta perumusan model ekonometrika yang mampu mengintegrasikan perubahan-perubahan eksternal maupun internal perdagangan gula di pasar dunia dan dampaknya terhadap industri gula domestik ke dalam suatu kebijakan yang komperhensif.

\section{Tujuan dan Manfaat Penelitian}


Tujuan umum dari penelitian ini adalah untuk mempelajari faktor-faktor yang mempengaruhi penawaran dan permintaan gula Indonesia dan menganalisis dampak dari pemberlakuan kebijakan impor dan harga gula Indonesia. Secara khusus, tujuan dari penelitian ini adalah :

1. Menganalisis faktor-faktor yang mempengaruhi penawaran dan permintaan gula Indonesia

2. Menganalisis dampak kebijakan tarif impor dan perubahan harga gula terhadap tingkat penawaran dan permintaan gula Indonesia

Manfaat hasil penelitian ini dapat dijadikan bahan masukan dalam membuat kebijakan dan strategi industri gula khususnya yang berkaitan dengan kebijakan tarif impor dan perubahan harga gula di pasar domestikIndonesia.

\section{TINJAUAN PUSTAKA}

\section{Karakteristik Gula Dunia}

Selaingula jagung, gula bit dan tanaman penghasil gula lainnya, gula berbasis tanaman tebu merupakan sumber utama dalam perdagangan gula dunia. Gula berbasis tebu selain lebih murah dibandingkan dengan tanaman penghasil gula lainnya proses pengolahaannya juga lebih mudah dan tidak eksklusif, tebu yang dipanen dan diproses pada pabrik gula akan menjadi gula mentah (non-food grade) dan selanjutnya disaring menjadi gula kristal (food grade). Karakterisitk untuk perdagangan gula akan bervariasi sesuai dengan kebutuhan spesifik dari konsumen pada pasar gula dunia, dengan volume perdagangan dan harga secara umum dikategorikan sebagai jenis gula mentah atau gula rafinasi.
Polaritas gula atau tingkat kemurnian penggilingan adalah pengukuran tingkat kualitas gula yang diperdagangkan juga merupakan kunci utama yang membedakan antara harga gula mentah dan gula rafinasi, seberapa dekat warna gula yang akan menjadi acuan untuk kemurnian (kandungan molasses) gula yang telah diolah dan isi dari dekstran kemurnian gula. Polaritas gula membedakan antara gula rafinasi dengan gula mentah dimana 100 persen polaritas menandakan kehalusan dan kemurnian gula dan dekstran adalah kandungan serat dari tanaman tebu yang diolah pada saat tebu dipanen yang cendrung membuat penyempurnaan pengolahan tebu menjadi lebih sulit. Ada empat jenis produk gula yang diperdagangkan pada pasar gula dunia berdasarkan tingkat polaritasnya, yaitu; i) gula rafinasi (gula putih), ii) semi rafinasi atau direct white, iii) very high polarity raw sugar (VHP) dan, iv) gula mentah standar.

\section{Profil industri gula Indonesia}

\section{Perkembangan luas areal tebu Indonesia}

Pertumbuhan luas areal tebu di Indonesia dari tahun 1980 sampai 2015 sebesar 1.03 persen atau seluas 389.691 hektar pertahunnya. Pada tahun 2015 luas areal perkebunan tebu di Indonesia mencapai 455 ribu hektar dimana perkebunan tebu di Indonesia sebagian besar diusahakan atau dikelola oleh rakyat. Kontribusi pengusahaan perkebunan tebu rakyat sebesar 64 persen dari total seluruh areal tebu Indonesia. Laju pertumbuhan perkebunan rakyat (PR) pada periode 1980 sampai 2015 rata-rata sebesar 2 persen atau sebesar 250.882 hektar 
pertahunnya. Luas areal tebu perkebunan besar swasta (PBS) menunjukan peningkatan sebesar 6 persen atau seluas 65.965 hektar setiap tahunnya. Peningkatan luas areal tebu perkebunan besar swasta tersebut dipicu oleh dukungan investasi pada peraturan menteri pertanian no. 98 tahun 2013 dan undang-undang no. 25 tahun 2007 tentang penanaman modal dimana merekomendasikan agar membuka sepenuhnya bidang usaha untuk penanaman modal asing. Luas areal perkebunan tebu di Indonesia terbesar berada di provinsi Sumatera Utara, Sumatera Selatan, Lampung, Jawa Barat, Jawa Tengah, D.I Yogyakarta, Jawa Timur, Gorontalo, dan Sulawesi Selatan. Dari sembilan areal tanam tebu tersebut provinsi Jawa Timur merupakan provinsi dengan luas areal perkebunan tebu yang terbesar. Pada tahun 2015 luas areal perkebunan tebu di provinsi Jawa Timur tercatat sebesar 45.44 persen dari total luasso areal tebu Indonesia atau seluas 207.15 hektar, Lampung meniliki luas areal tanam tebu sebesar 27.34 persen, Jawa Tengah sebesar 10.33 persen dan Sumatera Selatan sebesar 4.88 persen.

\section{Perkembangan produksi tebu Indonesia}

Produksi tebu (setara gula) Indonesia pada tahun 2013 sebesar 2.55 juta ton dan meningkat pada tahun 2014 sebesar 0.86 persen atau sebesar 2.77 juta ton. Pada tahun 2015 produksi tebu mengalami penurunan sebesar 1.9 persen atau sebesar 2.72. Persentase produksi tebu terbesar menurut pengusahaan tebu dimiliki oleh perkebunan rakyat (CIV) selama periode 2012 sampai 2014 sebesar 53.08 sampai 55.74 persen dan pada tahun 2015 pengusahaan tebu oleh CIV meningkat sebesar 14 persen dari tahun sebelumnya.

\section{Kebijakan industrigula Indonesia}

Tingginya tingkat distorsi pasar gula dunia dalam era liberalisasi perdagangan mengakibatkan meningkatnya harga gula International yang berpengaruh terhadap harga gula Indonesia. Pemerintah mengatasi peningkatan harga gula domestik dengan membuka impor dan memberikan subsidi harga pada pasar gula domestik agar konsumen mendapatkan harga gula yang murah.

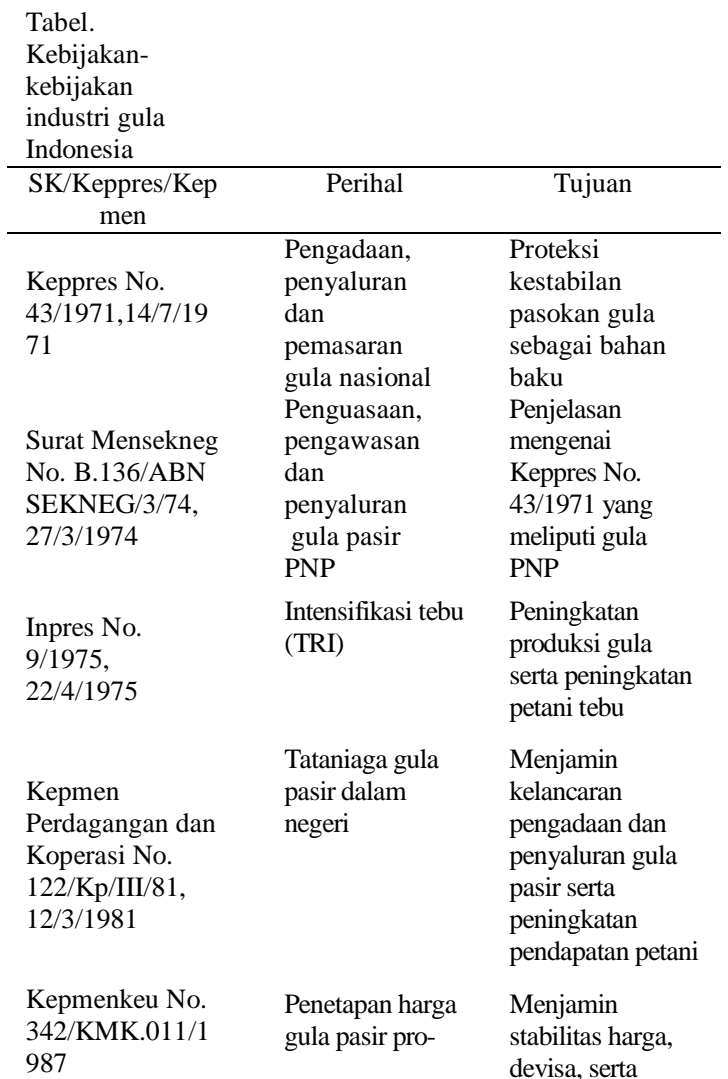




\begin{tabular}{|c|c|c|c|}
\hline & $\begin{array}{l}\text { duksi } \\
\text { dalam negeri dan } \\
\text { impor }\end{array}$ & $\begin{array}{l}\text { kesesuaian } \\
\text { pendapatan petani } \\
\text { dan pabrik }\end{array}$ & $\begin{array}{l}800 \text { per } \mathrm{kg} \\
\text { untuk gula } \\
\text { kristal putih }\end{array}$ \\
\hline $\begin{array}{l}\text { Inpres No. } \\
5 / 1997 \\
29 / 12 / 1997\end{array}$ & $\begin{array}{l}\text { Program } \\
\text { pengembangan } \\
\text { tebu rakyat }\end{array}$ & $\begin{array}{l}\text { Pemberian } \\
\text { peranan pada } \\
\text { pelaku bisnis } \\
\text { dalam rangka } \\
\text { perdagangan } \\
\text { bebas }\end{array}$ & $\begin{array}{l}\text { Meningkatkan } \\
\text { insentif petani } \\
\text { untuk tetap } \\
\text { menanam tebu } \\
\text { yang } \\
\text { diperlukan }\end{array}$ \\
\hline \multirow{2}{*}{$\begin{array}{l}\text { Inpres No. } \\
5 / 1998 \\
21 / 1 / 1998\end{array}$} & \multirow[t]{2}{*}{$\begin{array}{l}\text { Penghentian } \\
\text { pelaksanaan } \\
\text { Inpres No. } \\
5 / 1997\end{array}$} & \multirow{2}{*}{$\begin{array}{l}\text { Kebebasan pada } \\
\text { petani untuk } \\
\text { memilih } \\
\text { komoditas sesuai } \\
\text { dengan Inpres } \\
\text { No. } 12 / 1992\end{array}$} & $\begin{array}{l}\text { untuk mejaga } \\
\text { pasokan bahan } \\
\text { baku industri } \\
\text { gula }\end{array}$ \\
\hline & & & $\begin{array}{l}\text { Sumber : Susila } \\
2005, \text { KPPU } \\
2014,\end{array}$ \\
\hline $\begin{array}{l}\text { Kepmen } \\
\text { perindag } \\
\text { No.25/MPP/Kep/ } \\
\text { 1/1998 }\end{array}$ & $\begin{array}{l}\text { Pengaturan } \\
\text { tataniaga } \\
\text { komoditas impor }\end{array}$ & $\begin{array}{l}\text { Mendorong } \\
\text { efisiensi dan } \\
\text { kelancaran arus } \\
\text { barang }\end{array}$ & $\begin{array}{l}\text { Kementerian } \\
\text { perindustian } \\
\text { dan perdagangan } \\
2016\end{array}$ \\
\hline $\begin{array}{l}\text { Kepmenhutbun } \\
\text { No.282/Kpts- } \\
\text { XI/1999, } \\
7 / 5 / 1999\end{array}$ & $\begin{array}{l}\text { Penetapan harga } \\
\text { provenue gula } \\
\text { pasir } \\
\text { produksi petani }\end{array}$ & $\begin{array}{l}\text { Menghindari } \\
\text { kerugian petani } \\
\text { dan mendorong } \\
\text { peningkatan } \\
\text { produksi }\end{array}$ & $\begin{array}{l}\text { Wolgenant (1999) pada penelitian } \\
\text { FAO/United Nation yang berjudul Effect }\end{array}$ \\
\hline $\begin{array}{l}\text { Kepmenperindag } \\
\text { No. } \\
\text { 363/MPP/Kep/8/ } \\
\text { 1999, 5/8/1999 }\end{array}$ & $\begin{array}{l}\text { Tataniaga impor } \\
\text { gula }\end{array}$ & $\begin{array}{l}\text { Pengurangan } \\
\text { beban anggaran } \\
\text { pemerintah } \\
\text { melalui impor } \\
\text { gula oleh } \\
\text { produsen }\end{array}$ & $\begin{array}{l}\text { of Trade Liberalization on the World } \\
\text { Sugar Market bertujuan untuk } \\
\text { mempelajari perdagangan gula di pasar } \\
\text { dunia dengan sekenario pada }\end{array}$ \\
\hline $\begin{array}{l}\text { Kepermenindag } \\
\text { No. } \\
\text { 230/MPP/Kep/6/ } \\
\text { 1999, 5/6/1999 }\end{array}$ & $\begin{array}{l}\text { Mencabut } \\
\text { Kepmenperindag } \\
\text { No. } \\
\text { 363/MPP/Kep/8/ } \\
1999\end{array}$ & $\begin{array}{l}\text { Pembebanan tarif } \\
\text { impor gula untuk } \\
\text { melindungi } \\
\text { industri dalam } \\
\text { negeri. }\end{array}$ & $\begin{array}{l}\text { kesepakatan Uruguay Round atau GATT, } \\
\text { efek perjanjian liberalisasi terhadap } \\
\text { industri negara berkembang dan efek } \\
\text { liberalisasi perdagangan pada negara }\end{array}$ \\
\hline $\begin{array}{l}\text { Kepmenkeu No. } \\
324 / \text { KMK.01/20 } \\
02\end{array}$ & $\begin{array}{l}\text { Perubahan bea } \\
\text { masuk }\end{array}$ & $\begin{array}{l}\text { Peningkatan } \\
\text { efektivitas bea } \\
\text { masuk }\end{array}$ & $\begin{array}{l}\text { Brazil, China, Indonesia dan Korea. } \\
\text { Dampak liberalisasi perdagangan pada }\end{array}$ \\
\hline $\begin{array}{l}\text { Kepmenperindag } \\
\text { No.643/MPP/Ke } \\
\text { p/9/2002, } \\
23 / 9 / 2002\end{array}$ & $\begin{array}{l}\text { Tataniaga } \\
\text { impor gula }\end{array}$ & $\begin{array}{l}\text { Pembatasan } \\
\text { pelaku impor } \\
\text { gula hanya } \\
\text { menjadi } \\
\text { importir gula, } \\
\text { produsen dan } \\
\text { importir gula } \\
\text { terdaftar untuk } \\
\text { peningkatan } \\
\text { pedapatan } \\
\text { petani/produse } \\
\text { n }\end{array}$ & $\begin{array}{l}\text { pasar gula dunia dinyatakan bahwa } \\
\text { perubahan tingkat tarif pada tahun } 2000 \\
\text { dalam kesepakatan GATT/WTO akan } \\
\text { menaikan harga gula dunia sebesar } 7 \\
\text { persen atau peningkatan harga gula } \\
\text { dengan nilai sebesar US\$ } 0.12 \text { per pound. } \\
\text { Perubahan tingkat tarif yang }\end{array}$ \\
\hline $\begin{array}{l}\text { SK } \\
522 / \mathrm{MPP} / \mathrm{Kep} / 9 / \\
2004\end{array}$ & $\begin{array}{l}\text { Ketentuan } \\
\text { impor gula }\end{array}$ & $\begin{array}{l}\text { Revisi dan } \\
\text { mempertegas } \\
\text { Kepmenperind } \\
\text { ag No. } \\
\text { 643/MPP/Kep/ } \\
\text { 9/2002, } 23 \\
\text { September } \\
2002\end{array}$ & $\begin{array}{l}\text { diberlakukan negara-negara terbesar } \\
\text { selain menyebabkan perubahan harga } \\
\text { juga menimbulkan penurunan produksi } \\
\text { gula dunia yang dihasilkan negara } \\
\text { seperti; Amerika Serikat, EU, Jepang, }\end{array}$ \\
\hline $\begin{array}{l}\text { Kepmen } \\
\text { Perdagangan No. } \\
\text { 02/M/Kep/XII/2 } \\
004,7 / 08 / 2004\end{array}$ & $\begin{array}{l}\text { Perubahan } \\
\text { pada } \\
\text { kepmenperind } \\
\text { ag no. } \\
\text { 527/MPP/Kep } \\
\text { /9/2004 }\end{array}$ & $\begin{array}{l}\text { Impor gula } \\
\text { dapat } \\
\text { dilakukan } \\
\text { pada saat } \\
\text { persediaan } \\
\text { tidak } \\
\text { mencukupi } \\
\text { dan saat harga } \\
\text { tingkat petani } \\
\text { diatas Rp } 3\end{array}$ & $\begin{array}{l}\text { Australia, China, Indonesia, Philipina, } \\
\text { Mexico, Brazil dan Afrika Selatan. } \\
\text { Ekspor akan menurun pada negara EU, } \\
\text { Australia, Mexico dan Brazil namun } \\
\text { ekspor akan meningkat untuk negara } \\
\text { India dan Cuba terkait perubahan tarif }\end{array}$ \\
\hline
\end{tabular}


yang diberlakukan pada masing-masing negara tersebut. Banyak negara berkembang akan diuntungkan dari kesepakatan liberalisasi perdagangan dikarenakan hambatan tarif yang relatif lebih kecil dibandingkan negara maju dan volume impor akan berkurang untuk negara China, India, dan Indonesia. Pendapatan dari ekspor pada negaranegara terbesar penghasil gula akan berkurang sebesar 4 persen khususnya ekspor ke pasar Amerika Serikat dan EU yang memberlakukan tarif sebesar 20 persen di tahun 2005.

Abidin (2000) dalam penelitiannya mengenai dampak liberalisasi perdagangan terhadap keragaan industri gula Indonesia dengan tujuan membangun model ekonometrik industri gula, menganalisis perilaku dan meramalkan dampak liberalisasi perdagangan tahun 2000 sampai 2010 terhadap industri gula Indonesia. Rentang waktu dalam penelitian adalah tahun 1969 sampai 1997 yang diproses menggunakan program SAS/ETS menyatakan bahwa sebagian negara eksportir terbesar memberikan subsidi ekspor antara 8 persen sampai 102 persen, dan 30 persen negara eksportir memberlakukan pajak ekspor antara 6 persen sampai 52 persen. Negara importir sebanyak 54 persen termasuk Indonesia hanya memberikan subsidi impor antara 17 persen sampai 48 persen dan 46 persen negara berkembang lainnya memberlakukan tarif impor sebesar 7 persen sampai 173 persen, hal tersebut mendasari keberhasilan atau efektifitas dari kesepakatan dalam perdagangan liberal yang dipengaruhi oleh kesiapan untuk memberlakukan tujuan dan menghilangkan proteksi untuk impor dan ekspornya.
Susila (2005) dalam penelitiannya mengenai pengembangan industri gula Indonesia dengan analisis kebijakan dan keterpaduan sistem produksi dinyatakan bahwa terdapat tiga permasalahan utama dalam industri gula Indonesia, yaitu ; i) persaingan yang kurang adil (unfair) adalah awal dari tingkat distorsi atau proteksi perdagangan yang cenderung akan menurunkan harga gula di pasar international. Untuk komoditi gula negara-negara maju pada periode tahun 1999 sampai 2001 memberikan dukungan berupa subsidi senilai US\$ 6.35 milliar pertahun sementara nilai perdagangan sebesar US\$ 11.6 milliar pertahun, ii) kebijakan pemerintah belum efektif untuk mendorong perkembangan industri gula Indonesia, dan iii) inefisiensi di tingkat usahatani dan di PG. Pada penelitian ini ditawarkan beberapa alternatif kebijakan yaitu membuka industri gula Indonesia untuk menciptakan kondisi perdagangan pergulaan nasional yang lebih liberal tanpa adanya intervensi pemerintah, menetapkan tarif impor sebesar 25 persen, mencabut subsidi impor, tataniaga impor dan menghapus subsidi input. Kebijakan harga provenue Rp. 3400 per kg dengan TRQ (basis kuota 1 juta ton, tarif rendah Rp. 700 per kg dan tarif tertinggi Rp. 1300 per $\mathrm{kg}$ ) diharapkan dapat mengurangi dampak negatif dari kenaikan harga dasar gabah terhadap areal tebu dan produksi.

\section{Kerangka Teoritis}

\section{Pemberlakuan kebijakan tarif impor}

Tarif impor merupakan pajak yang dikenakan atas impor suatu barang dimana tarif tersebut akan cendrung menaikkan harga, menurunkan 
konsumsi, dan menaikkan produksi domestik (Samuelson dan Nordhaus2001). Kebijakan tarif ini bertujuan untuk mengurangi volume impor, namun disisi lain akan meningkatkan produksi dalam negeri melalui perbaikan harga. Pemberlakuan tarif impor akan menyebabkan kenaikan harga suatu produk di negara importir, penurunan konsumsi, peningkatan produksi, penurunan volume impor, dan adanya penerimaaan pemerintah yang berasal dari tarif impor tersebut. Pemberlakuan tarif impor ini akan menguntungkan produsen domestik karena harga impor suatu komoditas cendrung lebih tinggi daripada harga domestik. Kebijakan tarif impor pada negara kecil (small country) diasumsikan tarif yang dikenakan pada produk gula q pada pasar domestik adalah tarif yang dikenakan pada semua unit yang diimpor pada harga gula di tingkat domestik maupun dunia. Pada gambar 2.2 kondisi sebelum diberlakukannya tarif impor, harga gula berada pada titik $\mathrm{P}_{\mathrm{w}}$, harga gula dunia tersebut adalah harga yang diterima konsumen dan produsen gula domestik dengan jumlah impor sebesar $\mathrm{q}_{1}{ }^{\prime}-\mathrm{q}_{1}$. Pada saat negara importir memberlakukan kebijakan tarif impor sebesar $t$ maka terjadi pergeseran tingkat harga dari $\mathrm{P}_{\mathrm{w}}$ ke $\mathrm{P}_{\mathrm{w}}+\mathrm{t}$ dengan jumlah gula yang diimpor sebesar $\mathrm{q}_{2}$ ' $\mathrm{q}_{2}$. Kebijakan tarif impor pada small country akan menurunkan tingkat impor gula pada negara tersebut sebesar $\mathrm{q}_{1}{ }^{\prime}-$ $\mathrm{q}_{1}$ menjadi $\mathrm{q}_{2}^{\prime}-\mathrm{q}_{2}$. Analisis pada tingkat kesejahteraan dari pemberlakuan tarif impor akan menurunkan surplus konsumen sebesar $-\mathrm{a}-\mathrm{b}-\mathrm{c}$ dan $-\mathrm{d}$, dan meningkatkan surplus produsen sebesar + a. Pemerintah akan mendapatkan keuntungan yang didapatkan dari perhitungan jumlah gula yang diimpor setelah diberlakukan kebijakan tarif impor sebesar $\mathrm{q}_{2}{ }^{\prime}-\mathrm{q}_{2}$ dan penjumlahan dari tarif sebesar $\left[\left(\mathrm{P}_{\mathrm{w}}\right.\right.$ $+\mathrm{t})-\mathrm{P}_{\mathrm{w}}=\mathrm{t}$ ] dimana pada gambar 3.3 (a) ditunjukkan pada area c. Pada gambar 3.3 (b) kebijakan tarif impor diasumsikan diterapkan oleh negara besar atau large country dimana kebijakan tarif impor negara terbesar tersebut akan menurunkan tingkat impor untuk komoditas gula.

Pada kondisi sebelum diberlakukannya tarif impor harga gula yang diterima oleh pasar domestik sebesar harga gula dunia yaitu $\mathrm{P}_{\mathrm{w}}$ dengan jumlah gula yang diimpor sebesar $\mathrm{q}_{1}{ }^{\prime}-\mathrm{q}_{1}$. Pada saat pemberlakuan tarif impor dilakukan maka harga semula sebesar $\mathrm{P}_{\mathrm{w}}$ akan bergeser sejajar ke atas dengan penambahan tarif menjadi $\mathrm{P}_{\mathrm{w}}{ }^{\prime}+\mathrm{t}$ dan menurunkan jumlah gula yang diimpor sebesar $\mathrm{q}_{2},-\mathrm{q}_{2}$. Tarif impor yang diberlakukan tersebut dapat menurunkan jumlah gula yang impor sebesar $\mathrm{q}_{1}{ }^{\prime}-\mathrm{q}_{1}$ ke $\mathrm{q}_{2}{ }^{\prime}-\mathrm{q}_{2}$ dikarenakan negara tersebut merupakan negara terbesar yang dapat mempengaruhi tingkat harga dunia dan menurunkan permintaan gula dunia sebesar $\mathrm{P}_{\mathrm{w}}$ ke $\mathrm{P}_{\mathrm{w}}$, dengan tingkat penawaran yang bergeser sejajar ke bawah yang digambarkan pada garis horizontal $\mathrm{S}_{\mathrm{w}}$ ' Analisis kesejahteraan dari pemberlakuan tarif impor oleh negara terbesar akan mengakibatkan penurunan surplus konsumen sebesar $-\mathrm{a}-\mathrm{b}-\mathrm{c}$ dan $-d$, penambahan surplus produsen sebesar + a, dan penambahan pendapatan pemerintah sebesar $+\mathrm{c}$ dan + e. Pada pengenaan tarif impor tersebut akan menciptakan area $b$ dan $d$ yang merupakan nilai yang hilang atau 
deadweight loss dari pemberlakuan tarif. Pada dasarnya tarif tersebut dikenakan atas barang dan jasa merupakan kewajiban produsen untuk menanggungnya, dan pemerintah seharusnya dapat menjadikan area $b$ dan d sebagai pendapatan yang dikenakan atas pajak atau tarif impor tersebut namun pemerintah tidak dapat menerima sepenuhnya keuntungan dari penetapan tarif impor tersebut dikarenakan bahwa kerugian dari penerapan tarif merupakan excess burden dari pajak yang akan dibebankan kepada konsumen dan produsen (Block 2009). Penetapan tarif agar berada pada tingkat maksimum yaitu pada area e $-(b+d)$, tarif pada negara terbesar akan mendapatkan keuntungan ketika $\mathrm{e}>\mathrm{b}+\mathrm{d}$, dan mendapatkan kerugian ketika e $<\mathrm{b}+\mathrm{d}$. Kesimpulan untuk penetapan tarif impor yang diberlakukan pada small dan large country dirancang untuk mengurangi jumlah impor gula, meningkatkan produksi gula dan mengurangi tingkat konsumsi gula domestik. Pada kasus small country pemberlakuan tarif impor akan selalu menghasilkan penurunan tingkat kesejahteraan sosial secara keseluruhan dan pada large country akan memberikan hasil peningkatan tingkat kesejahteraan bersih atau mengurangi tingkat kesejahteraan sosial secara keseluruhan.

Dampak dari pengenaan tarif impor oleh negara importir dapat dijelaskan pada gambar kebijakan tarif impor. Dengan asumsi hanya ada dua negara yang memperdagangkan komoditas gula yaitu negara importir dan eksportir, tarif impor yang dilakukan adalah tarif impor spesifik dan negara importir adalah negara besar dimana jumlah importir akan berpengaruh terhadap perubahan harga gula di pasar dunia. $\mathrm{q}_{\mathrm{p}}(\mathrm{P})$ adalah kuantitas dari komoditas gula yang diimpor pada harga $\mathrm{P}, \mathrm{q}_{\mathrm{c}}(\mathrm{P})$ adalah kuantitas permintaan komoditas gula pada harga $\mathrm{P}$, dan $\mathrm{Q}_{\mathrm{e}}(\mathrm{P})$ adalah jumlah dari komoditas gula pada harga $\mathrm{P}$ di pasar dunia. Kondisi awal sebelum diberlakukannya kebijakan tarif impor gula, harga berada pada tingkat harga dunia $\mathrm{P}_{\mathrm{w}}$ dengan tingkat permintaan konsumen terhadap gula yang diperdagangkan sebesar $\mathrm{q}_{\mathrm{c}}$ dan produksi domestik sebesar $\mathrm{q}_{\mathrm{p}}$. Kurva ED menunjukkan besarnya biaya impor yang berpotongan dengan produksi gula yang ditawarkan ${ }_{5}^{\mathrm{E}}$ oleh negara pengekspor sepanjang garis ES.Apabila pemerintah negara A memberlakukan kebijakan tarif impor sebesar t maka

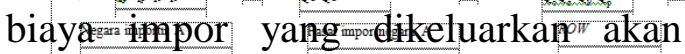

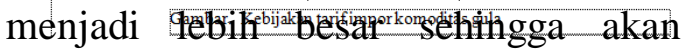
menggeser kurva ED sejajar ke bawah vertikal pada garis ED'. Pada kondisi setelah diberlakukannya tarif impor pada negara A harga impor yang diterima oleh konsumen akan meningkat (Koo, Kennedy 2005)

Kebijakan tarif impor tersebut akan menyebabkan penurunan tingkat kesejahteraan negara eksportir sebesar 2 $+3+4$ dan pada negara importir tingkat elastisitas penawaran ekspor akan menentukan tingkat kesejahteraan yang 
akan didapatkan. Dapat diketahui jika kebijakan tarif impor dikenakan pada tingkat yang tinggi maka akan memperbesar peningkatan kesejahteraan negara-negara di pasar dunia, berlaku sebaliknya jika tingkat tarif impor yang dilakukan negara eksportir kecil maka akan memperkecil tingkat kesejahteraan negara di pasar dunia dimana konsumen di negara importir akan menerima harga yang lebih rendah dibandingkan dengan harga di pasar dunia dan produsen di negara eksportir akan menerima harga yang lebih tinggi. Dampak perubahan kesejahteraan dengan adanya pemberlakuan tarif impor tersebut dapat dilihat pada Tabel berikut :

Tabel. Dampak kebijakan tarif impor terhadap kesejahteraan pelaku ekonomi

\begin{tabular}{|c|c|c|c|}
\hline $\begin{array}{l}\text { Analisis } \\
\text { kesejahteraan }\end{array}$ & $\begin{array}{c}\text { Negara } \\
\text { Importir } \\
\text { A }\end{array}$ & & ROW \\
\hline Surplus & - & & 1 \\
\hline konsumen & $(a+b+c+d)$ & & \\
\hline Surplus produsen & A & & $(1+2+3+4)$ \\
\hline Penerimaan Govt & $\mathrm{c}+\mathrm{e}$ & & - \\
\hline $\begin{array}{l}\text { Kesejahteraan } \\
\text { negara }\end{array}$ & $-(e+b+d)$ & & $-2-3-4$ \\
\hline $\begin{array}{l}\text { Kesejahteraan } \\
\text { dunia }\end{array}$ & - & $\begin{array}{l}- \\
(b+d+2+4)\end{array}$ & - \\
\hline
\end{tabular}

Indonesia adalah negara importir terbesar untuk komoditas gula, tingkat konsumsi adalah salah satu faktor yang menentukan jumlah impor komoditas gula. Impor gula dapat dinyatakan dalam persamaan berikut :

$M_{s}=C_{s}-Q_{s}+S_{s}$

dimana :

$\mathrm{M}_{\mathrm{s}}$ adalah jumlah impor gula, $\mathrm{C}_{\mathrm{s}}$ adalah jumlah konsumsi gula, $Q_{s}$ adalah jumlah produksi gula, dan $S_{s}$ adalah jumlah stok gula
Fungsi konsumsi yang menentukan impor atau permintaan gula dapat dinyatakan dalam persamaan berikut :

$C_{s}=f\left(P_{s}, P_{o}, Y\right.$, Pop,$\left.T_{s}\right) \ldots \ldots \ldots \ldots$

dimana :

$\mathrm{C}_{\mathrm{s}}$ adalah jumlah konsumsi gula, $\mathrm{P}_{\mathrm{s}}$ adalah harga gula, $\mathrm{P}_{\mathrm{o}}$ adalah harga komoditas subtitusi, $\mathrm{Y}$ adalah tingkat pendapatan, Pop adalah populasi penduduk, dan $T_{s}$ adalah selera

Dari persamaan konsumsi $\left(\mathrm{C}_{\mathrm{s}}\right)$ dapat diketahui jika konsumsi meningkat disebabkan oleh turunnya harga dan konsumsi akan berkurang jika terjadi peningkatan harga. Untuk memenuhi permintaan atau konsumsi suatu negara akan menentukan tingkat harga yang terendah, oleh karena itu nilai tukar atau kurs didefinisikan sebagai harga mata uang domestik akan mempengaruhi jumlah barang yang akan diimpor (Salvatrore, 1997). Persamaan impor dapat dinyatakan sebagai berikut :

$M_{s}=f\left(P_{s}, C_{s}, E R, M_{s(t-1)}, T M_{s}\right) \ldots \ldots \ldots \ldots$ (3.3)

dimana :

$M_{s}$ adalah jumlah impor gula, $P_{s}$ adalah harga gula, $C_{s}$ adalahjumlah konsumsi gula, $E R$ adalah nilai tukar, $M_{s}$ (t-1) adalahimpor gula tahun sebelumnya dan $T M_{s}$ adalah jika diasumsikan negar pengimpor memberakukan tarif impor dan subsidi impor.

$Q_{s}=A_{s} \mathrm{x} P_{s}$

$A_{s}=\left(P_{s}, C_{s}, E R, M_{s(t 1)}\right)$

Kebijakan Harga Pokok Petani Gula 
Harga pokok petani (HPP) untuk gula merupakan harga yang paling terkecil dalam lingkaran sistem perdagangan industri gula. Penentuan HPP ini menggunakan biaya pokok produksi (BPP) tebu atau gula petani, yang tujuan utànanya adălăh untuk méningkâtkan kesejahteraan petani dan pendapatan petani dalam upaya untuk meningkatkan produksi tebu dan produktivitas lahạ menuju swasembacta.guta. Selain itu kebijakan HPP ini bertujuan untuk memenuhi kébutuhian konsumsi gula domestik dengan prioritas harga yang relatif terjangkau. Dan kebijakan ini secara grafis dapat dilihat pada Gambar berikut :

Penetapan harga pokok petani (HPP) gula oleh pemerintah sebesar $\mathrm{P}_{1}$ mengakibatkan jumlah produksi gula menjadi sebesar $\mathrm{Q}_{2}$ dan jumlah yang diminta oleh konsumen sebesar $\mathrm{Q}_{1}$, hal tersebut selanjutnya direspon oleh konsumen yang akan menurunkan volume permintaannya jika harga gula meningkat dipasar domestik, sehingga kebijakan ini akan mencapai tujuannya jika pemerintah mengeluarkan alokasi anggarannya untuk membeli kelebihan produksi gula sebesar $\mathrm{Q}_{2}-\mathrm{Q}_{1}$ sehingga pengeluran untuk alokasi tersebut adalah sebesar $\mathrm{Q}_{1} \mathrm{EGQ}_{2}$. Surplus konsumen sebelum adanya kebijakan HPP ini adalah $\mathrm{P}_{0} \mathrm{BC}$, dan surplus produsen sebesar $\mathrm{P}_{0} \mathrm{BA}$, sedangkan setelah adanya kebijakan maka surplus konsumen berkurang menjadi $\mathrm{P}_{1}$ EC dan surplus produsen bertambah sebesar $\mathrm{P}_{1} \mathrm{GA}$.

\section{PERUMUSAN MODEL DAN PROSEDUR ANALISIS}

\section{Jenis, Sumber dan Pengolahan Data}

Dalam penelitian ini jenis data yang digunakan adalah data time series dengan rentang waktu 30 tahun yaitu dari tahun 1985 hingga 2015. Data time series dapat dikembangkan pada model dengan mudah, untuk meramalkan, menafsirkan, dan menghipotesis data ekonomi (Enders 2004). Data gula terkait dalam penelitian ini diperoleh dari instansi, lembaga dan organisasi baik secara langsung atau melalui publikasi yang diakses secara online, seperti Badan Pusat Statistik (BPS), Kementerian Perindustrian Republik Indonesia, Kementerian Pertanian Republik Indonesia, Kementerian Perdagangan Republik Indonesia, Dirjen Perkebunan Republik Indonesia, Badan Koordinasi Penanaman Modal (BKPM), Pusat Sosial Ekonomi dan Kebijakan Pertanian (PSEKP) dan Asosasi Gula Indonesia (AGI). Data gulaterkait dalam penelitian ini yang ditelusuri secara online melalui situs resmiInternational Sugar Organization (ISO), Intercontinental Exchange : Sugar No. 11 Futures (ICE), United States Development of Agricultural (USDA), World Bank, Food Agricultural Organization (FAO), 
Organisation for Economic Cooperation and Development (OECD), Global Agricultural Information Network (GAIN), Brazilian Sugarcane Industry Association (UNICA), International Commission for Uniform Methods of Sugar Analysis(ICUMSA), London International Financial Futures and Options Exchange(LIFE), Organization of Petrolieum Exporting Countries (OPEC), World Trade Organization (WTO) dan International Monetary Fund (IMF). Pengolahan data dalam penelitian ini akan diproses dengan menggunakan software SAS (Statistical Analysis System)seri 9.4 yang mampu memproses data statistik dengan cepat dan akurat (Sitepu dan Sinaga 2006) pada operating system Microsoft Windows.

\section{Luas areal perkebunan tebu Indonesia}

Perkebunan tebu Indonesia dalam penelitian ini terbagi menjadi tiga berdasarkan dengan status pengusahaan, yaitu perkebunan tebu negara, perkebunan tebu swasta dan perkebunan tebu rakyat. Areal tanam tebu di Indonesia dipengaruhi oleh harga gula dimana terdapat perbedaan antara harga gula pada masing-masing area

tanam tebu di Indonesia yaitu harga gula tingkat petani (mengikuti harga lelang dari hasil penggilingan tebu) pada area perkebunan rakyat dan area perkebunan negara dan swasta dipengaruhi oleh harga gula tingkat pedagang besar. Persamaan areal perkebunan tebu di Indonesia masingmasing dirumuskan sebagai berikut :

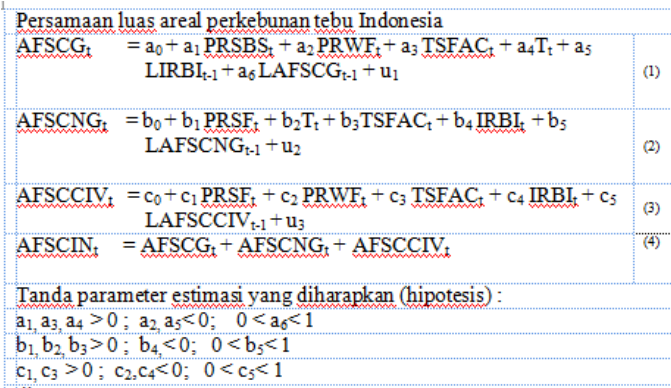

\section{Produktivitas gula hablur Indonesia}

Pada sistem produksi gula terdapat proses metabolisme tanaman tebu yang membentuk gula. Gula hablur pada produktivitas yang digunakan yaitu gula sukrosa yang dikristalkan. Proses pembentukan gula hablur dilakukan pada pabrik gula dimana tanaman tebu akan diproses melalui alat ekstraksi untuk mengeluarkan nira dari batang tebu yang selanjutnya diolah menjadi kristal. Hablur yang dihasilkan mencerminkan rendemen tebu, tinggi rendahnya hasil rendemen akan ditentukan oleh kondisi tanaman tebu dan proses penggilingan di pabrik (Data dan Fakta Gula, 2012). Untuk mendapatkan rendemen yang tinggi bibit tanaman tebu harus bermutu dan ditebang pada saat yang tepat serta didukung dengan sarana pabrik penggilingan yang baik. Produktivitas gula hablur Indonesia dikategorikan pada status pengusahaannya yaitu produktivitas gula hablur perkebunan negara, swasta dan rakyat. Berikut persamaan produktivitas gula hablur Indo nesia :

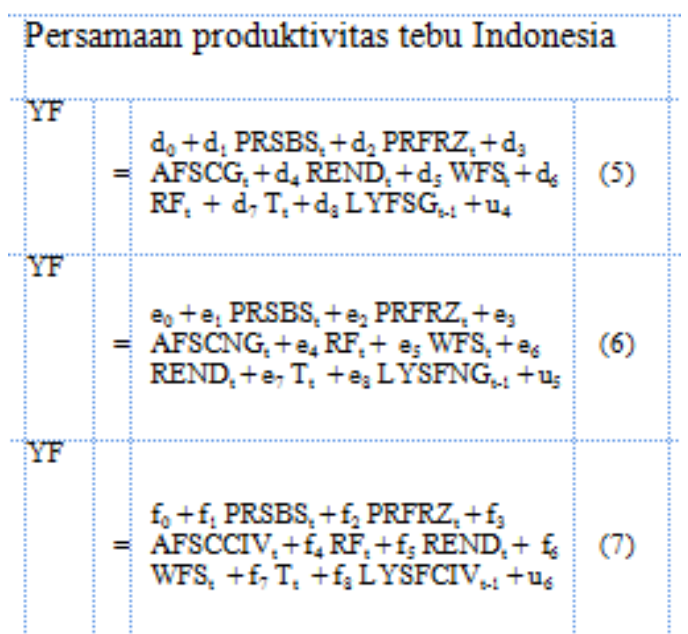




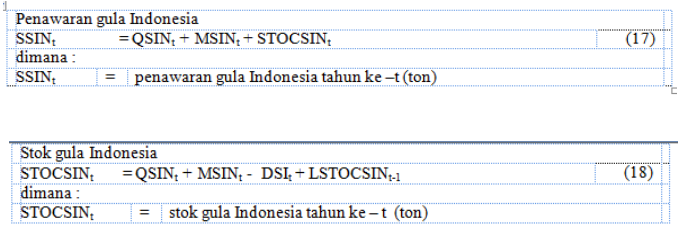

Tanda parameter estimasi yang diharapkan (hipotesis) adalah:

$\mathrm{d}_{3}, \mathrm{~d}_{4}, \mathrm{~d}>0 ; \mathrm{d}_{1}, \mathrm{~d}_{2}, \mathrm{~d}_{2}, \mathrm{~d}_{6}<0 ; 0<\mathrm{d}_{3}<1$

$e_{3} e_{6} e_{7}>0 ; e_{1}, e_{2} e_{4} e_{5}<0 ; 0<e_{3}<1$

$f_{3}, f_{5}, f_{7}>0 ; f_{1}, f_{2}, f_{4} f_{6}<0 ; 0<f_{8}<1$

dimana:

YFSC produktivitas tebu perkebumannegara tahun ke - $t$ (ton/ha)

YFSC

produktivitas tebu perkebunan swasta tahun ke - $t$ (ton/ha)

YFSC

produktivitas tebu perkebunan rakyat tahun ke - $t$ (ton/ha)

YFSCI

produktivitas tebu perkebuman Indonesia tahun ke-t (ton/ha)

Persamaan produksi gulaIndonesia \begin{tabular}{l|l} 
QSFG $_{\mathrm{t}}=$ & $\begin{array}{l}\mathrm{g}_{0}+\mathrm{g}_{1} \text { PRSBS }_{\mathrm{t}}+\mathrm{g}_{2} \mathrm{DSHH}_{\mathrm{t}}+\mathrm{g}_{3} \mathrm{PRFRZ}_{\mathrm{t}}+ \\
\mathrm{g}_{4} \mathrm{LQSFG}_{\mathrm{t}-1}+\mathrm{u}_{7}\end{array}$ \\
$\mathrm{QSFNG}_{\mathrm{t}}=$ & $\mathrm{h}_{0}+\mathrm{h}_{1} \mathrm{AFSNG}_{\mathrm{t}}+\mathrm{h}_{2} \mathrm{PRWF}_{\mathrm{t}}+\mathrm{h}_{3} \mathrm{DSHH}_{\mathrm{t}}+$
\end{tabular} QSFNG $_{\mathrm{t}}=\mathrm{h}_{\mathrm{o}}+\mathrm{h}_{1} \mathrm{AFSNG}_{\mathrm{t}}+\mathrm{h}_{2} \mathrm{PRWF}_{\mathrm{t}}+\mathrm{h}_{3} \mathrm{DSHH}_{\mathrm{t}}+$ QSFCIV $_{\mathrm{t}}=\mathrm{i}_{0}+\mathrm{i}_{1}$ AFSCIV $_{\mathrm{t}}+\mathrm{i}_{2}$ LPRSF $_{\mathrm{t}-1}+\mathrm{i}_{3}$

LQSFCIV $_{\mathrm{t}-1}+\mathrm{u}_{9}$ FNG + QSFCIV

Tanda parameter estimasi yang diharapkan (hipotesis)

$\mathrm{g}_{1}, \mathrm{~g}_{2}>0 ; \mathrm{g}_{3}<0 ; \quad 0<\mathrm{g}_{4}<1$

$\mathrm{h}_{1,} \mathrm{~h}_{3}>0 ; \mathrm{h}_{2}<0 ; 0<\mathrm{h}_{4}<$

$i_{1} i_{2}>0 ; 0<i_{3}<1$

dimana:

$\mathrm{QSFG}_{\mathrm{t}}=$ produksi gula perkebunan negara tahun $\mathrm{ke}-\mathrm{t}$

$\mathrm{QSFG}_{\mathrm{t}}=$ produksi gu

QSFNG $_{\mathrm{t}}=\frac{\text { (ton) }}{\text { produksi gula perkebunan swasta tahun } \mathrm{ke}-\mathrm{t}}$

QSFCI $_{t}=$ (ton)

$\begin{array}{ll}\mathrm{QSIN}_{t} & =\text { total produksi gula Indonesia tahun ke }-\mathrm{t} \text { (ton) }\end{array}$

Persamaan permintaan gula oleh rumah tangga Indonesia

$\mathrm{DSHH}_{\mathrm{t}}=\mathrm{j}_{\mathrm{0}}+\mathrm{j}_{1} \mathrm{PRSG}_{\mathrm{t}}+\mathrm{j}_{2}$ PRCOF F $_{\mathrm{t}}+\mathrm{j}_{3}$ POPIN $_{\mathrm{t}}+\mathrm{j}_{4} \mathrm{GDPR}_{\mathrm{t}}+\mathrm{j}_{5}$

Tanda parameter estimasi yang diharapkan (hipotesis) adalah :

$\mathrm{j}_{3}, \mathrm{j}_{4}>0 ; \mathrm{j}_{1} \mathrm{j}_{2}<0 ; 0<\mathrm{j}_{5}<1$

$\mathrm{DSHH}_{\mathrm{t}} \quad=$ permintaan gula oleh rumah tangga Indonesia tahun ke $-\mathrm{t}$ (ton)

Permintaan gula oleh industri di Indonesia

$\mathrm{DSI}_{\mathrm{s}}=\mathrm{k}_{\mathrm{O}}+\mathrm{k}_{\mathrm{L}} \mathrm{LPRSBS}_{\mathrm{L} 1}+\mathrm{k}_{2} \mathrm{PXFD}_{\mathrm{t}}+\mathrm{k}_{3} \mathrm{GDPR}_{4}+\mathrm{k}_{4} \mathrm{LDSI}_{\mathrm{L}}+\mathrm{u}_{12}$

Tanda parameter estimasi yang diharapkan (hipotesis) adalah

$\mathrm{k}_{2}>0 ; 0<\mathrm{k}_{1} \mathrm{k}_{3_{3}}, \mathrm{k}_{1}<1$

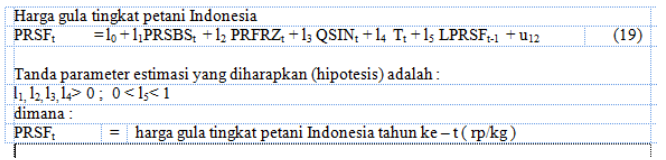

\section{Harga gula Indonesia}

\section{Identifikasi, Estimasi dan}

ValidasiModel Sistem Persamaan

Simultan

\section{Identifikasi model}

Model ekonomi gula yang telah dirumuskan dalam penelitian ini terdiri dari 22 persamaan yang terbagi menjadi 
16 persamaan struktural dan 6 persamaan identitas. Identifikasi model persamaan struktural disusun berdasarkan order condition dengan rumus (Koutsoyiannis 1977) ; (K-M) $\geq$ $(\mathrm{G}-1)$, dimana $\mathrm{G}$ adalah jumlah persamaaan (current endogenous variable), $\mathrm{M}$ adalah jumlah seluruh peubah atau variabel dalam model (endogenous andexogenous variable), dan $\mathrm{K}$ adalah total persamaan atau jumlah variabel endogen dalam model (current endogenous and predetermined). Apabila $(\mathrm{K}-\mathrm{M}) \geq(\mathrm{G}-1)$ maka persamaan teridentifikasi lebih banyak (over identified), $(\mathrm{K}-\mathrm{M})=(\mathrm{G}-1)$ maka persamaan teridentifikasi dengan tepat (exactly identified), dan jika (K$\mathrm{M}) \leq(\mathrm{G}-1)$ maka persamaan dikatakan tidak teridentifikasi (un-identified). Jumlah variabel terbanyak yang digunakan dalam persamaan adalah 8 variabel (M), sehingga model dalam penelitian ini (45-8) $\geq$ (22-1) persamaannya adalah over identified.

\section{Estimasi model}

Model dalam penelitian ini setelah dilakukan indentifikasi dengan hasil over identived, maka selanjutnya akan dilakukan proses estimasi model menggunakan metode 2SLS (Two Stage Least Squares). Metode 2SLS dikatakan tidak terlalu sensitif terhadap kesalahan spesifikasi model dan dapat memberikan estimasi parameter secara konsisten atau tidak bias. Untuk menjelaskan keragaman variabel endogen pada model dalam penelitian ini maka perlu diketahui dan diuji dengan menggunakan pengujian statistik F.

Metode pengujian uji statistik Durbin-h (Durbin Watson Statistics/d $d_{w}$ ) digunakan untuk mendeteksi adanya korelasi (autocorrelation) pada model yang tidak mengandung variabel bedakala. Pada penelitian ini pada persamaan mengandung variabel bedakala sehingga penelitian tidak menggunakan metode uji statistik Durbin-h untuk menghindari hasil yang tidak valid. Uji statistik $\mathrm{d}_{\mathrm{h}}$ atau Durbin$h$ statistics adalah metode yang digunakan untuk mengetahui keberadaan korelasi pada persamaan dengan variabel bedakala (Pindyck dan Rubenfield 1998). Formula Durbin- $h$ statisticsatau $\mathrm{h}_{\text {hitung }}$ adalah sebagai berikut :

$$
h_{\text {hitung }}=\left(1-\frac{d w}{2}\right)\left(\sqrt{\frac{N}{1-N(\operatorname{Var} \beta)}}\right)
$$

Pada formula Durbin-h statisticsatau $\mathrm{h}_{\text {hitung }}, d_{w}$ adalah nilai durbin watson hitung pada pengolahan melalui software SAS, $N$ adalah jumlah pengamatan contoh, $h$ adalah nilai statistik durbin $h$, dan var $\beta$ adalah varian dari koefisien lag endogenous. Taraf $\alpha=15$ persen digunakan untuk mengetahui $-1.96 \leq \mathrm{h}_{\text {hitung }} \leq 1.96$, dimana dapat disumpulkan bahwa persamaan tidak mengandung serial korelasi, apabila $\mathrm{h}_{\text {hitung }}<-1.96$ maka dalam persamaan terdapat autokorelasi negatif sebaliknya apabila $h_{\text {hitung }}>1.96$ maka dalam persamaan terdapat autokorelasi positif.

\section{Validasi Model}

Pada tahapan validasi model dalam penelitian ini dilakukan untuk mengetahui model yang digunakan dapat memproyeksikan keadaan perekonomian gula secara nyata. Kriteria yang digunakan pada tahapan validasi nilai estimasi model perilaku impor gula Indonesia di pasar dunia dalam penelitian ini adalah RMSPE (Root Mean Square Percent Error) dan 
$\mathrm{U}$ atau theil's inequality coefficient (Pindyck dan Rubinfield 1998). RMSPE digunakan untuk mengukur persentase penyimpangan nilai estimasi variabel endogen dari nilai aktual selama periode pengamatan, jika semakin kecil nilai RMSPE maka estimasi variabel endogen dalam penelitian semakin valid. Nilai statistik U dapat digunakan dalam mengukur validasi model untuk mengevaluasi kemampuan model menganalisis simulasi. Nilai statistik $U$ adalah antara 0 dan 1 , jika nilai $U=1$ maka estimasi variabel endogen tidak mendekati kenyataan dan jika $U=0$ maka estimasi variabel endogen sempurna atau mendekati kenyataan. Semakin kecil nilai RMSPE dan U maka estimasi variabel endogen semakin baik (Sitepu dan Sinaga 2006). Formula untuk RMSPE dan Udirumuskan sebagai berikut:

$$
\begin{gathered}
R M S P E=100\left[\frac{1}{T} \sum_{t=1}^{T}(P t-\right. \\
\left.\left.A t) / A_{t}\right)^{2}\right]^{0.5} \\
U=\frac{\sqrt{\frac{1}{T} \sum_{t=1}^{T}(P t-A t)^{2}}}{\sqrt{\frac{1}{T} \sum_{t=1}^{T} P_{t}^{2}}+\sqrt{\frac{1}{T} \sum_{t=1}^{t} A_{t}^{2}}}
\end{gathered}
$$

$T$ adalah jumlah periode pengamatan dalam simulasi, $P$ adalah nilai prediksi (predicted value) variabel endogen, dan $A$ adalah nilai pengamatan (actual value) variabel endogen.

\section{Simulasi Model}

\section{Simulasi historis (ex post simulation)}

Simulasi historis pada penelitian ini dilakukan untuk mengevaluasi kebijakan dan non kebijakan ekonomi di sektor pertanian terhadap permintaan dan penawaran, perdagangan, dan kesejahteraan pelaku ekonomi gula
Indonesia pada periode tahun 1985 sampai 2015. Distorsi pada pasar gula dunia pada analisis simulasi lebih lanjut akan melihat dampaknya terhadap perubahan tingkat kesejahteraan pelaku ekonomi gula Indonesia. Sekenario simulasi historis yang dilakukan pada penelitian ini adalah sebagai berikut :

1. Kebijakan penurunan tarif impor gula Indonesia pada skema GATT/WTO

Terdapat tiga aspek yang
dihasilkan pada
GATT/WTO dibidang pertanian yaitu ; i) pengurangan hambatan akses pasar berupa penurunan tarif rata-rata 36 persen dan minimum 15 persen untuk setiap jenis tarif di negara-negara maju dan untuk negara berkembang sebesar 24 persen, ii) pengurangan subsidi domestik dimana untuk negara maju sebesar 20 persen dan untuk negara berkembang wajib untuk mengurangi subsidi domestiknya sebesar 13.3 persen, dimana bentuk dari pemberian subsidi tersebut dihitung sebagai kredit dalam komitmen, dan iii) pengurangan subsidi ekspor untuk negara maju sebesar 36 persen dan negara berkembang pengurangan subsidi ekspor wajib diberlakukan sebesar 20 persen.

2. Kebijakan penurunan tarif impor gula Indonesia pada skema CEPT/AFTA

Pada skema CEPT/AFTA enam negara ASEAN (Brunei Darussalam, Indonesia, Malaysia, Philipina, dan Thailand) menetapkan penurunan 0 sampai 5 persen pada tahun 2002 dengan kondisi fleksibilitas atau kondisi apabila keenam negara tersebut belum mampu untuk menurunkan tarifnya hingga 0 persen maka akan ada kebijaksanaan untuk menurunkan 
tarifnya pada tahun 2003. Komoditas gula pada skema CEPT/AFTA termasuk pada kategori Sensitive list (SL) yang merupakan golongan produk unprocessed agricultural dimana dapat mengajukan banding penurunan tarifnya untuk jangka waktu yang lebih lama. Pada tahun 2015 Kementerian Pertanian menyatakan bahwa untuk produk gula Indonesia masih menerapkan tarif impornya sebesar 25 persen, dengan pertimbangan bahwa kondisi industri gula Indonesia masih mengalami defisit produksi. Pertimbangan atas penetapan tarif impor tersebut berdasarkan keputusan menteri keuangan nomor nomor 546/KMK.01/2003 disebutkan bahwa Indonesia akan menimbang pemberlakuan sisitem klasifikasi barang impor berdasarkan ASEAN Harmonized Tariff Nomencleature (AHTN) dalam skema CEPT/AFTA.

3. Kebijakan peningkatan harga pokok gula tingkat petani

Pemerintah menetapkan harga pokok petani (HPP) gula kristal putih (GKP) salah satunya berdasarkan penyesuaian perhitungan biaya produksi. Melalui peraturan menteri perdagangan (Permendag) nomor 42/MDAG/PER/5/2016 tentang penetapan HPP GKP tahun 2016 pemerintah menetapkan HPP sebesar Rp. 9100 per $\mathrm{kg}$ atau naik sebesar 2.25 persen dari tahun sebelumnya sebesar Rp. 8900 per kg. Pemerintah akan menjamin melalui Bulog untuk membeli gula dari petani dengan HPP sebesar Rp. 9100 per kg.

4. Penambahan luas areal tanam tebu

Dalam peraturan menteri pertanian Repulik Indonesia No. 19/permentan/HK.140/4/2015 tentang rencana strategis Kementrian Pertanian tahun 2015-2019 dikatakan bahwa keberlanjutan sektor pertanian tanaman pangan dihadapi pada ancaman luas tanam yang terus menurun akibat konversi lahan pertanian produktif ke penggunaan non-pertanian yang terjadi secara masif. APTRI mengatakan untuk menembus target produksi gula diperlukan sekitar 280 ribu hektar atau 42 persen dari total luas areal tanam tebu Indonesia saat ini yang mencapai 480 ribu hektar.

\section{Revitalisasi pabrik gula Indonesia}

Pemerintah melalui kementerian BUMN dan PTPN X akan berencana untuk menutup 10 pabrik gula yang rata-rata berusia diatas 100 tahun secara bertahap dengan mengubah fungsi menjadi pabrik pupuk atau pabrik maintanance untuk mengurangi biaya produksi pabrik-pabrik gula lainnya melalui pemutusan rekanan terkait peralatan dan infrastruktur pendukung produksi gula Indonesia. Dengan diberlakukannya kebijakan tersebut maka diharapkan pabrik yang beralih fungsi dapat menjadikan pendukung tercapainya efisiensi kinerja pabrik penggilingan tebu di Indonesia khususnya pulau Jawa.

\begin{tabular}{|c|c|c|c|}
\hline \multicolumn{4}{|r|}{ LAMPIRAN } \\
\hline \multicolumn{4}{|c|}{ Tabel 1. Variabel-variabel endogen: } \\
\hline \multicolumn{4}{|c|}{ Luas areal tanam tebu Indonesia: } \\
\hline 1 & $\mathrm{AFSCG}_{\mathrm{t}}$ & & luas areal tebu perkebunan negara tahun $k e-t$ (ha) \\
\hline & $\mathrm{AFSCNG}_{\mathrm{t}}$ & $=1$ & luas areal tebu perkebunan swasta tahun $\mathrm{ke}-\mathrm{t}(\mathrm{ha})$ \\
\hline & $\mathrm{AFSCCIV}_{\mathrm{t}}$ & & luas areal tebu perkebunan rakyat tahun ke $-\mathrm{t}$ (ha) \\
\hline & $\operatorname{AFSCIN}_{t}$ & & total luas areal tebu Indonesia tahun $\mathrm{ke}-\mathrm{t}(\mathrm{ha})$ \\
\hline \multicolumn{4}{|c|}{ Produktivitas perkebunan tebu Indonesia : } \\
\hline 5 & $\mathrm{YFSCG}_{\mathrm{t}}$ & & \multirow{4}{*}{ 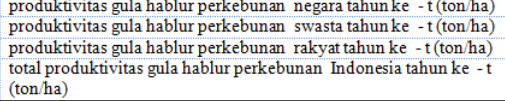 } \\
\hline & $\mathrm{YFSCNG}_{\mathrm{t}}$ & & \\
\hline 7 & $\mathrm{YFSCCIV}_{\mathrm{t}}$ & & \\
\hline 8 & YFSIN $_{t}$ & & \\
\hline \multicolumn{4}{|c|}{ Produksi tebu perkebunan Indonesia : } \\
\hline 9 & $\mathrm{QSCFG}_{\mathrm{t}}$ & \multicolumn{2}{|r|}{ produksi tebu perkebunan negara tahun $\mathrm{ke}-\mathrm{t}$ (ton) } \\
\hline 10 & $\mathrm{QSCFNG}_{\mathrm{t}}$ & $=\mathrm{r}$ & \multirow{2}{*}{$\begin{array}{l}\text { produksitebu perkebunan swasta tahun ke } \mathrm{t} \text { (ton) } \\
\text { produksi tebu perkebunan rakyat tahun } \mathrm{ke}-\mathrm{t} \text { (ton) }\end{array}$} \\
\hline 11 & $\mathrm{QSCFCIV}_{\mathrm{t}}$ & \multirow{2}{*}{\multicolumn{2}{|c|}{$\begin{array}{l}=\text { produksi tebu perkebunan rakyat tahun ke }-\mathrm{t} \text { (ton) } \\
=\text { produksi tebu Indonesia tahunke }-\mathrm{t} \text { (ton) }\end{array}$}} \\
\hline \multirow{2}{*}{\multicolumn{4}{|c|}{ Produksi tetes tebu Indonesia : }} \\
\hline & & & \\
\hline \multicolumn{4}{|c|}{13} \\
\hline \multicolumn{4}{|c|}{ Tabel. 2. Variabel-variabel Eksogen : } \\
\hline 1 & $\mathrm{PRWF}_{\mathrm{t}}$ & & $=$ harga gabah tingkat petani tahun $\mathrm{ke}-\mathrm{t}(\mathrm{rp} / \mathrm{kg})$ \\
\hline & TSFAC $_{t}$ & & $=$ jumlah pabrik gula Indonesia tahun $\mathrm{ke}-\mathrm{t}$ (unit) \\
\hline & & & $=$ trend waktu tahun $k e-t$ \\
\hline & $\mathrm{IRBI}_{\mathrm{t}}$ & & $=$ suku bung bank Indonesia tahun ke $-t(\%)$ \\
\hline & PRFRZ $_{1}$ & & $=$ harga pupuk tahun $\mathrm{ke}-\mathrm{t}(\mathrm{rp} / \mathrm{kg})$ \\
\hline & $\mathrm{REND}_{t}$ & & $=$ rendemen tebu Indonesia pada tahun $\mathrm{ke}-\mathrm{t}(\%)$ \\
\hline & $\mathrm{WFS}_{\mathrm{t}}$ & & $=$ upah pekerja sektor perkebunan tahun ke $-\mathrm{t}($ pp hari $)$ \\
\hline 8 & $\mathrm{RF}_{\mathrm{t}}$ & & $=$ curah hujan Indonesia tahun ke $-\mathrm{t}(\mathrm{mm} / \mathrm{tahun})$ \\
\hline & PRCOF $_{t}$ & & $=$ harga kopi Indonesia tahun $\mathrm{ke}-\mathrm{t}(\mathrm{p} / \mathrm{kg})$ \\
\hline 10 & POPIN $_{t}$ & & $=$ jumlah penduduk Indonesia tahun ke $-\mathrm{t}$ (jiwa) \\
\hline 11 & $\mathrm{GDPR}_{\mathrm{t}}$ & & $=\begin{array}{l}\left(\mathrm{GDP}_{\mathrm{t}}-\mathrm{GDP}_{\mathrm{t}-1}\right) / \mathrm{GDP}_{\mathrm{t}-1}: \text { pertumbuhan Gros Domestik Bruto Indonesia } \\
\text { tahun ke }-\mathrm{t}\end{array}$ \\
\hline 12 & $\operatorname{PXFD}_{t}$ & & 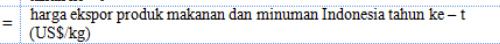 \\
\hline 13 & POW $_{t}$ & & $=$ harga minyak mentah dunia tahun $\mathrm{ke}-\mathrm{t}$ (US\$ barel) \\
\hline 14 & $\mathrm{QSW}_{\mathrm{t}}$ & & $=$ produksi gula dunia tahun $\mathrm{ke}-\mathrm{t}$ (ton) \\
\hline 15 & TMSIN $_{t}$ & & $=$ tarif impor gula Indonesia tahun ke $-\mathrm{t}(\%)$ \\
\hline
\end{tabular}




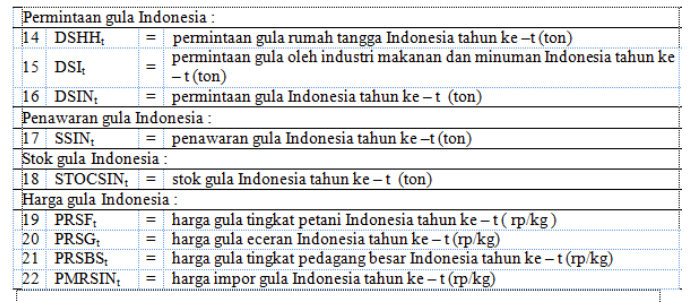

\section{DAFTAR PUSTAKA}

Abidin Z. 2000. Dampak Liberalisasi Perdagangan terhadap Keragaman Industri Gula Indonesia: Suatu Analisis Kebijakan [disertasi]. Bogor (ID) : Institut Pertanian Bogor.

[AGFAE] Asociacion General de Fabricaantes de Azucar de Espana. 1992. El Azucar en LaEspana Contemporanea. hal, 57. Madrid, (ESP)

Alas M. 1996. The Impact of Trade Liberalization by Major Importing and Exporting Countries on World Sugar Trade [disertasi]. University of Colorado (US)

Alvarez J, Polopolus LC. 2008. Sugar and the General Agreement on Tariffs and Trade. University of Florida, Gainesville, FL, (US)

Aradhey A. 2016. India : Sugar Annual Report 2016, USDA/GAIN (US)

Arifin B. 2008. Indonesian Sugar SelfSufficency, Economic
Review ${ }_{s}$ No. 211, Jakarta

Ball R J. 1973. The International Linkage of National Economics Models. NorthHolland Publisihng Company, Amesterdam, (NLD)

Balistreri E,. Jensen J, Tarr D. 2015. What Determines Wheater Prefential Liberalization of Barriers againts Foreign Investors in Services Are Beneficial or Immizerising: Application of the Case of Kenya, Vol.9,2015-42

Barros S. 2016. Brazil : Sugar Annual Report 2016, USDA/GAIN

Benirschka M, Koo W W, Lou J. 1996. World Sugar Policy Simulation Model Description and Computer Program Documentation, Agriculture Economics Report No. 356, Departement of Agricultural Economics, North Dakota State, (US)

Block CD. 2009. Corporate Taxation Examples \& Explanations, Ed ke - 4, Aspen publishers, (US)

Breguet P. 2012. Impact of Australian Sugar Policy on the World Sugar Economy. FAO $12^{\text {th }}$ Sugar Conferene. Fiji, (JPN)

[BPS] Badan Pusat Statitstik. 2015. Statistik Tebu Indonesia, Jakarta

[BPS] Badan Pusat Statitstik. 2016. Statistik Perdagangan Luar Negeri-Impor, Jakarta

[CEPT-AFTA] The Common Effevtive Preferential Tariff scheme for the ASEAN Free Trade Area. 1992. Singapura Chatenay PH. 2013. Government Support and the Brazilian Sugar Industry. a report for American Sugar Alliance (UK) 
Dardis R, Warner E. 1967. Measures of the Degree and Cost of Economic Protection of Agriculture in Selected Countries : Issue 1384, USDA, Economic Research Services

Data dan Fakta Gula. 2012. Berbagai Istilah terkait Gula

Departemen Perindustrian. 2009. Roadmap Industri Gula, Direktorat Jendral Industri Agro dan Kimia, Jakarta

Dirjen Perkebunan. 2014. Statistik Perkebunan Indonesia 20132015, Jakarta

Diewert WE, Morrison CJ. 1986.Export Supply and Import Demand Functions : A Production Theory Approach, National Beureu of Economic Research, Cambridge (US)

[EC] European Commision. 2012. Statistical and Economic Information Report 2012, Directorate-General for Agriculture and Rural Development

Enders W. 2004. Applied Econometric Time Series. Ed ke-2. Wiley. Alabama (US)

Fairtrade Foundation. 2013. Fairtrade and Sugar, Commodity Briefing

Farrell R. 2015. Australia : Sugar Annual 2015, GAIN report no: AS1508, USDA (US)

[FAO] Food and Agriculture Organization. 1997. Impact of Trade Liberalization on the World Sugar Market. Economic and Social Develompment Departement. Pasific sugar conference,
Fiji (JPN)

Flach B et. al. 2016. EU-28 Biofuels Annual 2016, GAIN report no : NL6021, USDA (US)

Funk SM, Zook JE, Featherstone AM. 2008. Chicago Board of Trade Ethanol Contract Efficency. Southern Agricultural Economics Association Annual Meeting, Dallas (US)

Galloway J H. 2000.Sugar The Cambridge World History of Food, Cambridge University Pr (UK)

Gujarati D. 2004. Basic Econometrics. Ed ke - 4. McGraw Hill Inc, New York (US)

Goldin I, Knudsen O. 1990.Agricultural Trade Liberaliation : Implication for Developing Countries. ): OECD.Paris (FRA)

Gonarsyah I. 1983. An Econometric Analysis of the U.S- JapanKorea Market for U.S White Wheat, Departement of Agriculture and Resource Economics, Oregon State University

Hill C, Griffiths W, Judge G. 1997. Undergraduate

Econometric. John Wiley \& Son, Inc. Canada (US)

Hubbard M. 2003. Developing Agricultural Trade New Roles for Government in Poor Countries. Palgrave Macmillan (UK)

Houck JP. 1986. Elements of Agicultural Trade Policies. Macmillan Publisihng Company, A Division of Macmillan, Canada (US)

[ICUMSA] International Commission for Uniform Methods of Sugar Analysis. 2009. 
Polarimetry and the International Sugar Scale. ISCUMSA Method SPS-1. Berlin (DEU)

[IMF] International Monetary

Fund.2009.Export and Import, Price, Index, Manual Theory and Practice, IMF Multimedia Services Section (US)

[ISJ] International Sugar Journal. 2015. ISJ's World Sugar Outlook 2015. De Smet. Informa. (UK)

Johnson GL. 1986. Research Methodology for Economists, Philosophy and Practice. Macmillan Publisihng Company, A Division of Macmillan. New York, (US)

Kementrian Pertanian.2016. Outlook Tebu Komoditas Pertanian Subsektor Perkebunan, Pusat Data dan Sistem Informasi Pertanian Sekertariat Jendral, ISSN 1907-1507, 2016, Jakarta

Koutsoyiannis A. 1977. Theory of Economoetrics. Ed ke - 2 . Macmillan Publisihng Company, A Division of Macmillan, London (UK)

Krishnan B, Bousso R. 2016. Oil up 7 percent as Iran welcomes output freeze without word on cuts, Reuters, Commodities, 17 Februari 2016

Krugman PR, Obstfeld M. 2003.International Economics Theory and Policy, World Student Series, Ed ke - 6. The Addison-Wesley. Boston (US)

[KPPU] Komisi Pengawas
Persaingan Usaha. 2014. Laporan Tahunan KPPU 2014. Biro hukum, Humas dan KPPU, Jakarta

[LIFE] London International Financial Futures and Options Exchange. 2016. London Daily Price, contract no. 407, (EU)

Macedo IC. 2007. Sugar cane's Energy, Twelve studies on Brazilian Sugar cane agribusiness and its sustainability. UNICA, Sao Paulo (BRZ)

Mairon G, Lima B. 2012.

Malian A H. 2004. Kebijakan Perdagangan International Komoditas Pertanian Indonesia, PSEKP, AKP. Vol 2 No. 2, Juni 2004, Bogor

Messrs, Akiyama T, Corbin M. 1997. The Japanese Sugar Market.FAO Corporate document repositry. Fiji (JPN)

Mitchell D O. 2005. Sugar Policies: An Opportunity for Change. Global Agricultural Trade and Developing Countries. Chapter. 8. GAT (US)

Nainggolan K. 2000. Constraints and Consequences of Trade Liberalization on Agriculture in Indonesia. Paper presented at the Seminar on Policy Analysis of Linkages between Indonesia's Agricultural production, 12 Juni 2000, Jakarta

Neuman W L. 2003. Social Research Methods, Qualitiative and Quantitative Approaches. Ed ke - 5. Pearson Education Inc. Boston, (US)

Nyberg J. 2006. Sugar International 
Profile, FAO, (US)

OECD/FAO. 2007. OECD-FAO Agricultural Outlook 20072016. Sekjen OECD dan Dirjen FAO, (US)

[OPEC] Organization of Petrolieum Exporting Countries. 2016. Annual OPEC oil price from 1960 to 2016, The Statistics Portal

Outlaw JL, Richardson JW. 2016. Analysis of the Coalition for Sugar Reform Amandements to U.S Sugar Policy : Potential Effect on Policy and Industry, American Sugar Alliance, Texas A\&M University, 17 Mei 2016, (US)

Owiye PO, Naibei, IK, Momanyi G. 2016. Effect of Trade Liberalization of Performance of Sugar Firms in Kenya: The Case of Government Owned Firms, European Scientific Journal, vol 12, No. 13. doi : 10.19044/esj.2016.v12n13p30 6.

Phillips L. 2012. Overview \& OutlookBrazillian Sugarcane Industry, UNICA, North America

Pindyck R S dan Rubinfield DL.1998. Econometric Model and Economic Forecast. Ed ke - 4, McGraw hill, New York (US)

Prasertsri P. 2016. Thailand: Sugar Annual Report 2016, report No. TH5047, USDA (US)

Porter C. 2016. World Agricultural Prospects The Road to 2050, Supply Intelligence Ltd

Rahman RY. 2013. Prospek Perdagangan Gula Indonesia dalam Implementasi Kerangka Perjanjian Perdagangan Bebas ASEAN-China. [tesis]. Bogor (ID) : Institut Pertanian Bogor.

[RFA] Renewable Fuels Association.
2016. Fueling A High Octane Future, 2016 Ethanol Industry Outlook, tersedia pada : www.EthanolIRFA.org

Rezbova H, Belova A, Skubna O. 2013, Sugar Beet Production in the European Union and their Future Trends. Agris in Economics and Informatics, Faculty of Economics and Management,vol 5, No 4, Pregue, (CZE)

Samuelson PA, Nordhus WD. 2001. Economics. Ed ke - 17. McGraw hill. Virginia, (US)

Salvatore D, Hagen JV. 1997. Macroeconomic Policy in Open Economies. Greenwood Press. (US)

Sekjen Kementrian Pertanian. 2014. Outlook Komoditi Tebu, Pusat Data dan Sistem Informasi Pertanian, ISSN 1907-1507, Jakarta

Susila W R. 2005. Pengembangan Industri Gula Indonesia: Analisis Kebijakan dan Keterpaduan Sistem Produksi. [disertasi], Bogor (ID) : Institut Pertanian Bogor

Sitepu K R, Sinaga B M. 2006. Aplikasi Model Ekonometrika : Estimasi, Simulasi, Peramalan menggunakan program SAS, Program Studi Ilmu Ekonomi Pertanian, Bogor (ID) : Institut Pertanian Bogor

Tim Dampak AEC. 2016. Laporan Dampak ASEAN Economic Community terhadap Sektor Industri Sektor Industri dan Jasa serta Tenaga Kerja di Indonesia, No. Lap10/KF.4/2014, Jakarta

Tweeten L. 1989. Agriculture Policy and Analysis Tools for Economic Development. 
Westview Press Inc, Boulder \& San Francisco, (US)

[UNICA] Brazilian Sugarcane Industry Association. 2017. UNICAData tersedia pada : http://www.unicadata.com.br/i ndex.php

VanGreasstek C. 2013. The History and Future of the World Trade Organization. WTO, Atar Roto Press SA, Geneva (SWZ)

Valdes C, Hjort K, Seeley R. 2016. Oil Price and Ethanol Demand Drive Change in Agricultural Commodity Production in Brazil, Amber Waves, USDA, (US)

Wijaya A. 2000. Dampak Liberalisasi Perdagangan terhadap Kinerja Ekonomi Indonesia : Suatu Pendekatan

Makroekonometrika.

[disertasi], Bogor (ID) : Institut Pertanian Bogor

Wright T, Meylinah. 2016. Indonesian Sugar Annual Report 2016, GAIN report No. ID1614, 21 Maret 2016, USDA (US)

Wohlgenant M K. 1999. Effect of Trade Liberalization on the World Sugar Market, Sugar and Baverages Group, Raw Materials, Tropical and Horticultiral Products Service Commodities and Trade Division, FAO of United Nations, Rome (ITA)

Woo WW, Kennedy PL. 2005. International Trade and Agriculture. Blackwell. Victoria (AUS) 